Egyptian Journal of Aquatic Biology \& Fisheries

Zoology Department, Faculty of Science,

Ain Shams University, Cairo, Egypt.

ISSN $1110-6131$

Vol. 25(4): 857 - 869 (2021)

www.ejabf.journals.ekb.eg

\title{
Analysis of Plankton Intake to the Growth and Omega-3 Fatty Acid Content of Milkfish (Chanos chanos Forsskal, 1775)
}

\section{Endang Y. Herawati ${ }^{1 *}$, Anik M. Hariati ${ }^{2}$, Qurrota A'yunin ${ }^{2}$, Ruly I. Khasanah,}

${ }^{1}$ Department of Aquatic Resources Management, Faculty of Fisheries and Marine Sciences, Brawijaya University, Malang 65145, East Java, Indonesia

${ }^{2}$ Department of Aquaculture, Faculty of Fisheries and Marine Sciences, Brawijaya University, Malang 65145, East Java, Indonesia

${ }^{3}$ Post Graduate Program, Faculty of Fisheries and Marine Sciences, Brawijaya University, Malang 65145, East Java, Indonesia

${ }^{4}$ Department of Marine Science, Faculty of Science and Technology, UIN Sunan Ampel, Surabaya 60237, East Java, Indonesia

"Corresponding Author: eyulih@yahoo.co.id or herawati_ey@ub.ac.id

\section{ARTICLE INFO}

Article History:

Received: March 8, 2021

Accepted: May 28, 2021

Online: Aug. 30, 2021

Keywords:

Growth,

Milkfish,

Omega-3,

Fatty acid,

Plankton.
ABSTRACT

The aim of the present study was to examine the food, growth, and omega 3 fatty acid content of milkfish (Chanos chanos) in Sidoarjo fish pond, East Java. The study was conducted by spreading 5,000 fish milkfish seeds $(5-7 \mathrm{~cm}$ long and $0.6-1.0 \mathrm{~g}$ ) to the fish pond. The length and weight of milkfish were measured, and the digestive tract was isolated. For sampling, a plankton net was used and samples were preserved in $1 \%$ Lugol solution. Data were analyzed to determine the food type and selection, growth rate, relative intestine length, and weight length relationship. The recorded relative intestine length of milkfish was 5.4-6.4 cm and was categorized as herbivorous fish. The food type was phytoplankton with a length of $<14 \mathrm{~cm}$ and zooplankton with a length of $>15$ $\mathrm{cm}$. The proportion of zooplankton in the fish intestine increased with its size. The phytoplanktons found dominantly in the digestive tract were Chaetoceros sp. and Nitzschia sp. and zooplankton were Calanus sp. and Cyclop sp. The daily length growth rate ranged from 0.008 to $0.283 \mathrm{~cm}$, while the daily weight growth rate ranged from 0.5 to $1.16 \mathrm{~g}$. The length-weight relationship of milkfish (Chanos chanos) can be determined by equation $\mathrm{W}=0.1466 \mathrm{x}$ with the regression index $\mathrm{R} 2=1$. Thus, milkfish (Chanos chanos) tended to have isometric growth patterns with the length and weight and were directly proportional to the omega-3 content in the milkfish body.

\section{INTRODUCTION}

Milkfish (Chanos chanos) is a beneficial source of fatty acid required for health. Agustini et al. (2010), mentioned that Chanos chanos is a source of unsaturated fat in the form of omega-3 with a percentage of $19.56,7.4 \%$ omega- 6 , and $19,24 \%$ omega-9. The high content of omega-3 in this fish is due to excistance of plankton and microalgae that produce a lot of omega-3 and fatty acids and are eaten by the specific fish (Estiasih, 2009). Fish has significant chemical content including high protein. Futhermore, milkfish 
fat has more double bond, which is an unsaturated fatty acid. Omega-3 are an unsaturated fatty acids that do not convert to cholesterol in the body, Tus it can decrease blood cholesterol levels (Suptijah, 1999).

Recently, diet with enough sea fish, especially phytoplankton-eating fish, can reduce the risk of coronary heart disease because it inhibits the atheroclerosis process by reducing blood cholesterol, triglyceride and LDL levels and also increasing HDL. Futhermore, the potentials of omega 3 fatty acids to affect the immune system (Calder, 2007; Chapkin et al. 2009) by improving the cell membrane function and increasing low density lipoprotein (LDL) oxidation (Mahrus, 2008). It can also suppress or reduce the risk of chronic hereditary diseases has been proven, including diabetes (Rudkowska, 2010), coronary heart disease (Car \& Webel, 2012; Xin et al, 2012), atherosclerosis (Miles \& Calder, 2012), anti-cancer, tumors (Cockbain et al. 2012; Vaughn et al. 2013) and decrease blood cholesterol.

The composition of fats and fatty acids in fish varies in accordance to species, season, geographical location, gonad maturity level and fish size (Stansby, 1967; Kusumo, 1997). Markedly, marine phytoplankton is a primary source of omega 3 in the food chain. PUFAs derived from marine organisms usually exists in the form of triglycerides, although it can be in other forms such as esters or phospholipids (Berge \& Barnathan, 2005). Fish oil from the Scombroidae, Clupeidae and Salmonidae families has the highest EPA and DHA (Rodriguez et al. 2010). Milkfish (Chanos chanos) is a common type of plankton-eating fish with the main food of diatoms, filamentous green algae and detritus (Rao \& Sivani 1996; Franklin et al. 2006; Prayitno et al. 2015). The existence of Chanos chanos is act mainly to control plankton populations and increase the catch of fishermen at Ir. H. Djuanda Reservoir in July to August 2008 was about 2,116,000 fishes (Tjahjo \& Purnamaningtyas, 2009). The introduced Chanos chanos in those waters are able to utilize plankton abundance and possess a very fast growth rate $(\mathrm{K}$ $=3.381$; with $\mathrm{L} \infty=45 \mathrm{~cm}$ ).

Chanos chanos has a very wide salinity tolerance, ranging from saltwater (35 ppt) to freshwater ( $0 \mathrm{ppt})$, so that it can be maintained in saltwater until freshwater (Coad, 2015). Chanos chanos as a commodity of brackish and saltwater has been widely known in the community for a long time (Chong et al., 1984). This fish has been used as a source of animal protein for coastal communities and trade commodities with a quite high price. Chanos chanos is a very important source of animal protein in Southeast Asia too, and is widely cultivated in fishpond areas in Philippines, Indonesia and Taiwan. The length of the fish in sea waters is $\pm 100 \mathrm{~cm}$ and can reach to a maximum of $180 \mathrm{~cm}$ (Nelson et al. 2016). Thus, the purpose of this study was to examine the food, growth and omega- 3 fatty acids content from milkfish (Chanos chanos) in fish pond at Sedati District, Sidoarjo, East Java. 


\section{MATERIALS AND METHODS}

\section{Milkfish seeds}

Milkfish seeds were obtained from Marine and Fisheries Polytechnic and fish ponds at Sedati District, Sidoarjo (Fig.1) with average length of 5-7 cm, weight of 0.6-1.0 $\mathrm{g}$ and age of about 3 months. The seeds harvested are temporarily accommodated in an aerator equipped reservoir. Transported with a closed system using plastic bags that were given oxygen. In each plastic bag, a volume of 30 litres was added to \pm 500 Chanos chanos seeds, then pure oxygen gas was added to the water: air with a ratio of 1: 2 .

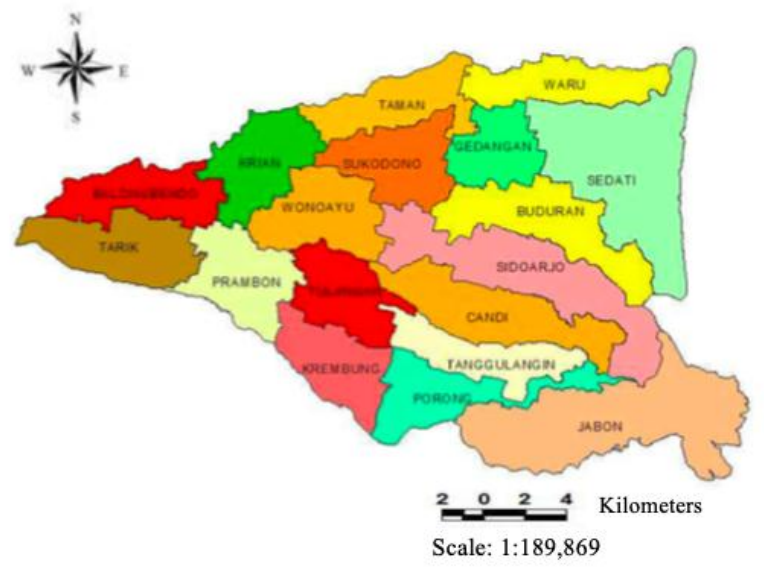

Fig. 1. Sidoarjo Map (Faradina et al. 2015)

Chanos chanos specimens were obtained by catching once a month from March to August 2018, using $1.25 ; 1.5 ; 1.75 ; 2.0$ inches mesh size of gill net with the help of local fishermen. Each specimen was stored in a fish storage box and taken to a laboratory to measure the total length and weight, and analyze the contents of the digestive system. The total length was measured from the tip of the upper jaw to the tip of the tail using a metal bar to the nearest millimetre. Weight of fish was weighed using an electrical scale with a precision of 0.1 gram. The type of Chanos chanos was observed by opening the stomach, removing intestinal contents, then identifying the species under a microscope using a plankton identification manual (Shirota 1996; Verlencar 2004; Barsanti \& Gualtieri, 2006).

\section{Sampling of Plankton}

Plankton sampling was carried out by filtering water using an $86 \mu \mathrm{m}$ eye opening plankton net. Water was taken using a 5 litre- bucket six times so that the total filtered water was 30 lites, then $30 \mathrm{ml}$ filtered water was added lugol to $4 \%$ content and stored in plastic bottles. Plankton sampling location was the same as the location of the installation of gill nets. 


\section{Plankton abundance}

Each bottle of preserved plankton sample was shaken by flipping the bottle and then $1 \mathrm{ml}$ was taken with the use of a pipette, then carefully poured evenly into the Sedgwick-Rafter Counting Cell. Plankton samples were examined under light microscope. Using taxonomic keys, the species or the genera level was identified and calculated (Shirota 1996; Verlencar 2004; Barsanti \& Gualtieri, 2006). The total abundance of plankton was calculated using equation (1): Formula of total abundance of plankton was calculated as follows:

$$
\mathrm{N}=\operatorname{ni} \times\left(\mathrm{Vr} / \mathrm{V}_{0}\right) \times\left(1 / \mathrm{V}_{\mathrm{s}}\right) \times 1000
$$

Note: $\mathrm{N}=$ total number of individuals (cells, ind) plankton/liters, $\mathrm{ni}=$ Number of cells or individuals observed in the $n=1$ species, $V_{r}=$ volu 'me of filtered water $(30 \mathrm{ml}), V_{o}=$ volume of water observed at Sedgwick- Rafter $(1 \mathrm{ml}), \mathrm{V}_{\mathrm{s}}=$ volume of filtered water (30 liters), $1000=$ conversion of litres into $\mathrm{m}^{3}$ units.

\section{Food}

The relative proportion of the intestinal length to body length is used to determine the trophic level of fish. Based on the relative intestinal length, fish are divided into carnivores (<1), omnivores (1-3), and herbivores (>3) (Biswas, 1993).

$$
\text { Relative intestinal length }=\frac{\text { intestinal length }}{\text { body lenght }}
$$

The largest index was used to analyze the types of fish food and assess the types of food most eaten by fish. The largest part index analysis was calculated according to equation (3):

$$
\mathrm{I}_{\mathrm{i}}=\frac{V i . O i}{\sum_{n}^{\mathrm{i}=1} \operatorname{Vi}_{\mathrm{i} . O i}} \times 100
$$

Note: $\mathrm{I}_{\mathrm{i}}=$ the largest index, $\mathrm{V}_{\mathrm{i}}=$ percentage of volume of $\mathrm{i}$-type fish food, $\mathrm{O}_{\mathrm{i}}=$ percentage of frequency occurrence of $n$-type food, $n=$ number of fish food organisms ( $i$ $=1,2,3, \ldots \mathrm{n})$.

\section{Growth in Length and Weight}

The average length of Chanos chanos was calculated using equation (4):

$$
\mathrm{L}_{\mathrm{t}}=\sum \frac{L i}{n}
$$

Note: $\mathrm{L}_{\mathrm{t}}=$ average length $(\mathrm{cm})$ of fish at age $\mathrm{t}$ (sampling time), $\mathrm{L}_{\mathrm{i}}=$ length of fish $\mathrm{i}, \mathrm{n}=$ number of fish measured in length.

The average weight of Chanos chanos was calculated using equation (5):

$$
\mathrm{W}_{\mathrm{t}}=\sum \frac{W i}{n}
$$

Note: $\mathrm{W}_{\mathrm{t}}=$ mean weight of fish at age $\mathrm{t}(\mathrm{g}), \mathrm{W}_{\mathrm{i}}=$ weight of fish to $\mathrm{i}(\mathrm{g}), \mathrm{n}=$ number of fish weighed.

\section{Omega 3 Fatty Acids Content}

Fatty acid extraction was carried out following the method of Bligh and Dyer (1959) after methylated using themethod of Morisson and Smith (1964). Three Chanos 
chanos from each sampling were taken and the abdomen were cleaned. Subsequently, they were left in the sun to dry. The dried fish were taken in the Dorso-lateral part of the body and mixed, then weighed as much as one gram, then crushed in a glass cup and extracted by adding $10 \mathrm{ml}$ of petroleum ether (PE), centrifuged at 3000rpm for 2 minutes and filtered. Next, the mixture was allowed to stand for about 15 minutes so that the petroleum ether would evaporate and fat was obtained. The fat was then methylated by adding $10 \mathrm{ml}$ of $\mathrm{BF} 3$ in methanol $(\mathrm{BF} 3 \mathrm{CH} 3 \mathrm{OH}) 20 \%$ then was shaken with a shaker for about 30 minutes. The top layer, containing the fatty acid methyl ester, was separated and analyzed using Gas Chromatography (GC).

\section{RESULTS}

\section{Milkfish Chanos chanos seeds}

The number of the stocking fish was 5,000 specimens . The Chanos chanos had a total length range of 3.5-5.0 cm with an average of $4.21 \pm 0.45 \mathrm{~cm}$ and weight of $0.3-1.0$ $\mathrm{g}$ with an average of $0.55 \pm 0.20 \mathrm{~g}$. Chanos chanos were first caught using gill nets with 1.25-inch eye openings net in mid-March. They were grouped into four classes with a diameter of $5 \mathrm{~cm}$, and the smallest group got lengths $<15 \mathrm{~cm}, 16-20 \mathrm{~cm}, 21-25 \mathrm{~cm}$, and the largest were $>26 \mathrm{~cm}$.

\section{Types of Plankton}

The composition of plankton species in fish ponds at Sedati district, Sidoarjo is presented in Table (1). Nine species of phytoplankton were found in ponds; namely, Chaetoceros sp., Nitzschia sp., Spirogyra sp., Surirella elegana, Synedra, Tabellaria sp., Melosira sp., Navicula sp. and Pleurosigma sp. While zooplankton in the pond were eight species, including Branchionus sp., Calanus sp., Copepoda sp., Cyclop sp., Daphnia sp., Diaptomus sp., Euglypha sp., and Euterpina sp. Phytoplankton species most found were Chaetoceros sp., but with respect to zooplankton, Cyclop sp was the most identified.

\section{The presence of types of food}

The types of phytoplankton found in the Chanos chanos digestive tract consisted of Chaetoceros sp., Nitzschia sp., Pleurosigma sp., Spirogyra sp., Surirella and Synedra sp. The zooplankton species found were Branchionus sp., Calanus sp., Cyclop sp., Daphnia sp., and Diaptomus sp. The presence of food types from the phytoplankton group ranged from $31.31 \%$ to $67.24 \%$, and the most abundant was Chaetoceros sp. In the zooplankton group, the presence of zooplankton foods ranged from 46.55 to $69.83 \%$. The variation in the presence of types of food in the phytoplactone group was greater than in the zooplankton group.

\section{Food Types Composition}

The composition of the types of food consumed by Chanos chanos consisted of phytoplankton and zooplankton (Table 2). It appears that the larger the size of the fish, the more type of food is turned into zooplankton. 
Table 1. The mean abundance of phytoplankton (cell $/ \mathrm{m}^{3}$ ) and zooplankton (ind $/ \mathrm{m}^{3}$ ).

\begin{tabular}{|c|c|c|c|c|c|c|c|c|}
\hline Species & April & May & June & July & August & September & Average & $\%$ \\
\hline \multicolumn{9}{|c|}{ PHYTOPLANKTON } \\
\hline Chaetoceros sp. & 89.091 & 145.750 & 19.800 & 190.575 & 145.750 & 19.800 & 101.794 & 20,6 \\
\hline Melosira sp. & 56.818 & 80.300 & 18.150 & 154.963 & 11.550 & 18.150 & 56.655 & 11,4 \\
\hline Navicula sp. & 18.182 & 29.700 & 7.150 & 55.825 & 29.700 & 7.150 & 24.618 & 5,0 \\
\hline Nitzschia sp. & 46.364 & 70.950 & 11.550 & 107.800 & 70.950 & 143.413 & 75.171 & 15,2 \\
\hline Pleurosigma sp. & 0 & 0 & 5.000 & 60.638 & 68.750 & 5.000 & 23.231 & 4,7 \\
\hline Spirogyra sp. & 50.455 & 74.250 & 17.050 & 143.413 & 74.250 & 17.050 & 62.745 & 12,7 \\
\hline Surirella $\mathrm{sp}$ & 52.727 & 68.750 & 15.950 & 142.450 & 68.750 & 11.550 & 60.030 & 12,1 \\
\hline Synedra sp. & 63.636 & 81.950 & 18.150 & 165.550 & 81.950 & 18.150 & 71.564 & 14,5 \\
\hline Tabellaria sp. & 0 & 0 & 4.091 & 49.088 & 56.818 & 4.091 & 19.015 & 3,8 \\
\hline Total & 377.273 & 551.650 & 116.891 & 1.070 .302 & 608.468 & 244.354 & 494.823 & \\
\hline \multicolumn{9}{|c|}{ ZOOPLANKTON } \\
\hline Branchionus sp. & 0 & 0 & 30.250 & 43.313 & 30.250 & 43.313 & 24.521 & 3,5 \\
\hline Calanus sp. & 68.182 & 99.550 & 117.700 & 223.300 & 117.700 & 223.300 & 141.622 & 20,2 \\
\hline Copepoda & 0 & 0 & 27.500 & 55.825 & 69.545 & 55.825 & 34.783 & 5,0 \\
\hline Cyclop sp. & 79.545 & 123.750 & 145.750 & 263.725 & 145.750 & 79.545 & 139.678 & 20,0 \\
\hline Daphnia sp. & 75.000 & 107.250 & 77.000 & 140.525 & 77.000 & 140.525 & 102.883 & 14,7 \\
\hline Diaptomus sp. & 69.545 & 88.000 & 115.500 & 212.713 & 79.545 & 212.713 & 129.669 & 18,5 \\
\hline Euglypha sp. & 65.909 & 83.600 & 86.900 & 153.038 & 86.900 & 153.038 & 104.898 & 15,0 \\
\hline Euterpina sp. & 0 & 0 & 14.300 & 30.800 & 14.300 & 69.545 & 21.491 & 3,1 \\
\hline Total & 358.181 & 502.150 & 614.900 & 1.123.239 & 620.990 & 977.804 & 699.544 & \\
\hline
\end{tabular}

Table 2. The composition of Chanos chanos food based on length of fish groups.

\begin{tabular}{ccccc}
\hline $\begin{array}{c}\text { Length class } \\
(\mathrm{cm})\end{array}$ & $\begin{array}{c}\text { Number of } \\
\text { sample }\end{array}$ & $\begin{array}{c}\text { Mean } \\
\text { weight }(\mathrm{g})\end{array}$ & $\begin{array}{c}\text { Dominant food } \\
\text { group }(\%)\end{array}$ & $\begin{array}{c}\text { Dominant food type } \\
(\%)\end{array}$ \\
\hline$<15$ & 9 & 17,4 & Fitoplankton (96) & Nitzschia sp. (62) \\
$16-20$ & 6 & 50,2 & Fitoplankton (84) & Chaetoceros sp. (83) \\
$21-25$ & 30 & 95,6 & Zooplanton (68) & Cyclop sp. (37) \\
$>26$ & 19 & 150 & Zooplankton (58) & Calanus sp. (38) \\
\hline
\end{tabular}

\section{Food composition and selection}

The composition of plankton species in pond waters and Chanos chanos food types is presented in Fig. (2). There were 9 species of phytoplankton in pond waters, while the phytoplankton species found in Chanos chanos intestines were 6 species. Similarly, zooplankton that exist in waters were 8 species, while those found in the intestines of Chanos chanos were only 5 species. Phytoplankton that were not found in 
the intestines of Chanos chanos were: Melosira sp., Navicula sp., and Tabellaria sp., while zooplankton that were not found in the intestines of Chanos chanos were Copepoda sp., Euglypha sp., and Euterpina sp.

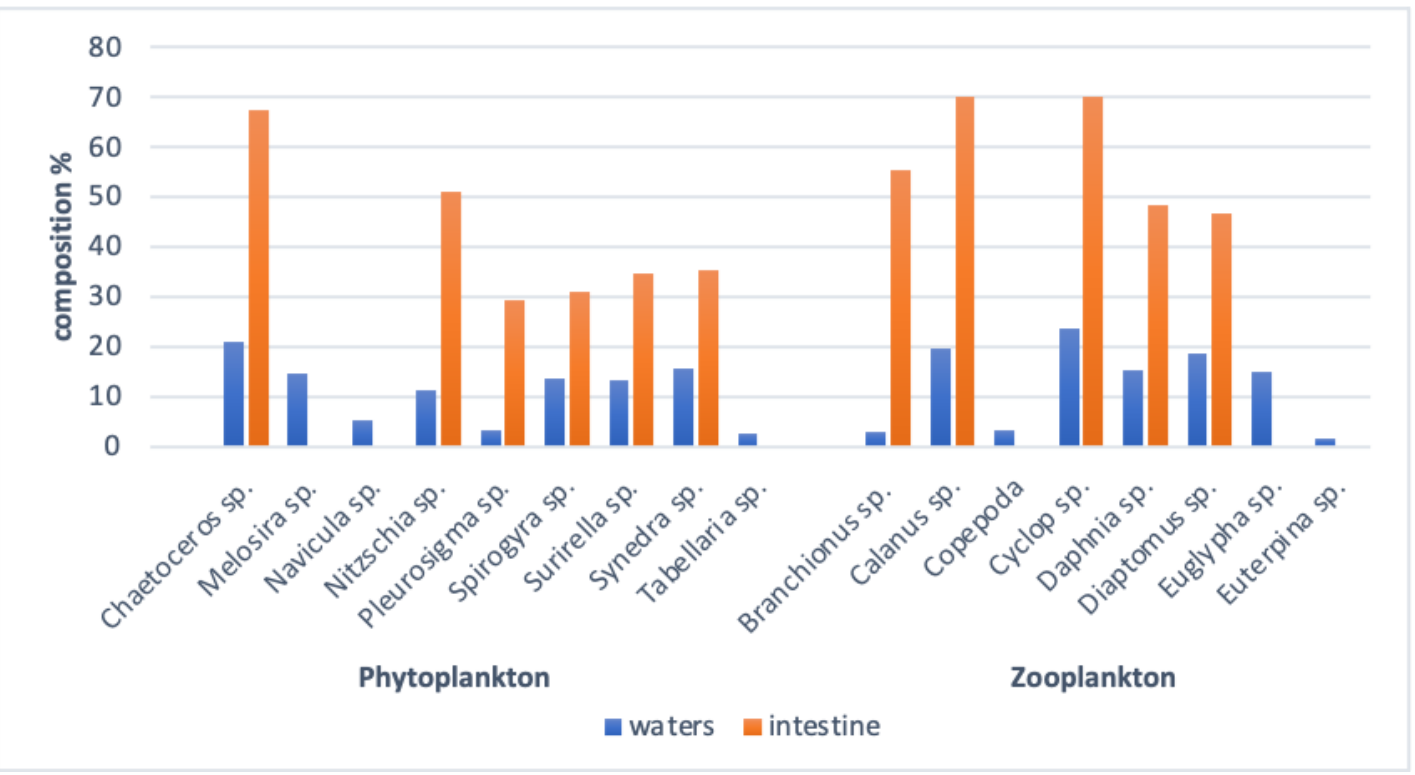

Fig. 2. Proportion of types of plankton in water ponds and intestines of Chanos chanos.

\section{Relative length intestines}

Relative intestine length indicates the type of food consumed by Chanos chanos in ponds which is presented in Table (3). Based on the average relative intestinal length, Chanos chanos is classified as herbivorous fish. The greater the length of Chanos chanos, the longer the average length of the intestine is.

Table 3. The relative length of Chanos chanos intestine based on the length groups in Sedati District of Sidoarjo.

\begin{tabular}{ccccccc}
\hline $\begin{array}{c}\text { Length } \\
\text { class } \\
(\mathrm{cm})\end{array}$ & $\begin{array}{c}\text { Number of } \\
\text { sample }\end{array}$ & $\begin{array}{c}\text { Intestine } \\
\text { length } \\
(\mathrm{cm})\end{array}$ & $\begin{array}{c}\text { Average } \\
\text { intestine } \\
\text { length }(\mathrm{cm})\end{array}$ & $\begin{array}{c}\text { Relative } \\
\text { intesine } \\
\text { length }\end{array}$ & $\begin{array}{c}\text { Average } \\
\text { relative } \\
\text { intestine } \\
\text { length }\end{array}$ & Note \\
\hline$<15$ & 7 & $59-83$ & 70.4 & $4.4-5.7$ & 5.4 & Herbivore \\
$16-20$ & 22 & $81-134$ & 104.5 & $4.3-6.8$ & 5.5 & Herbivore \\
$21-25$ & 70 & $94-86$ & 137.7 & $4.1-8.7$ & 5.8 & Herbivore \\
$>26$ & 17 & $152-200$ & 174 & $5.7-6.9$ & 6.4 & Herbivore \\
\hline
\end{tabular}

\section{Growth Length and Weight of Fish}

The total number of Chanos chanos caught during the study was 125 fishes. The number of samples captured each sampling month from April to September were 8, 15, $24,26,30,22$, respectively, with a range of 3.5-29.5 cm long and weights of 0.9-197.5 g. 
The growth and length of the absolute weight of Chanos chanos every month are presented in Fig. (3). In general, the length and weight of Chanos chanos measured every month gave a rapid change in length and weight from the time of stocking (April) till November. At the beginning of the dry season (July), fish expressed a slowing down in length and weight growth.

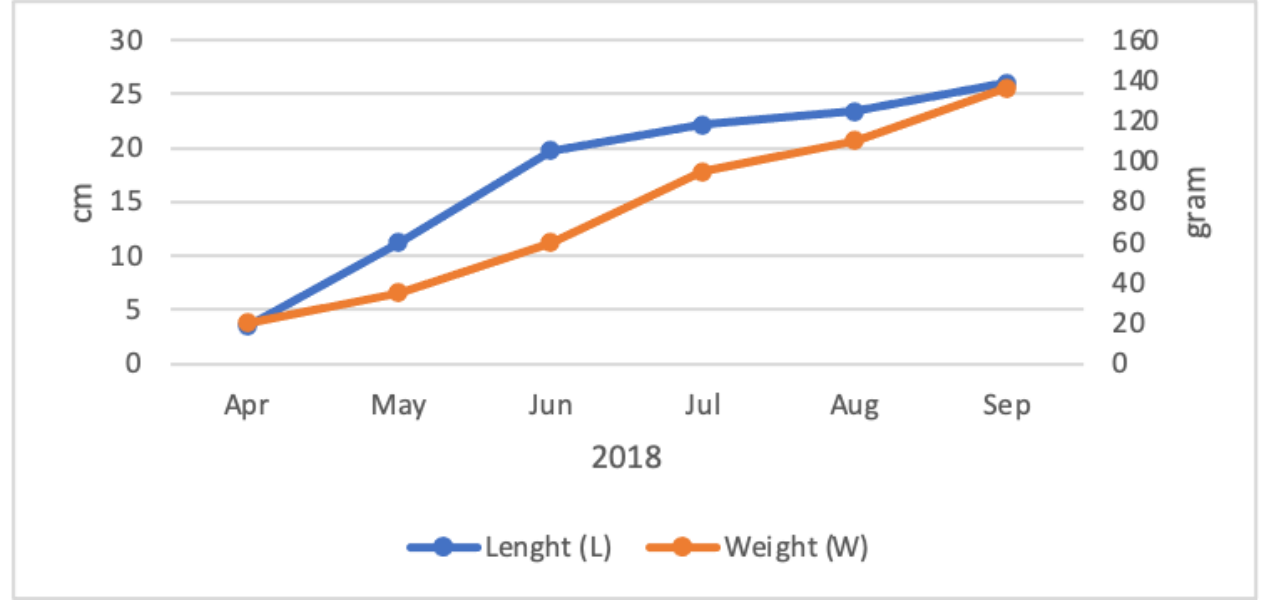

Fig. 3. Mean length and weight of Chanos chanos in April-September 2018.

\section{The Relationship of Length and Omega-3 fatty acid content}

The number of Chanos chanos samples used for the analysis of the lenght-weight relationship were 125 fishes, which is the total catch during sampling in March - August. The lenght-weight relationship of Chanos chanos is presented in Fig. (4).

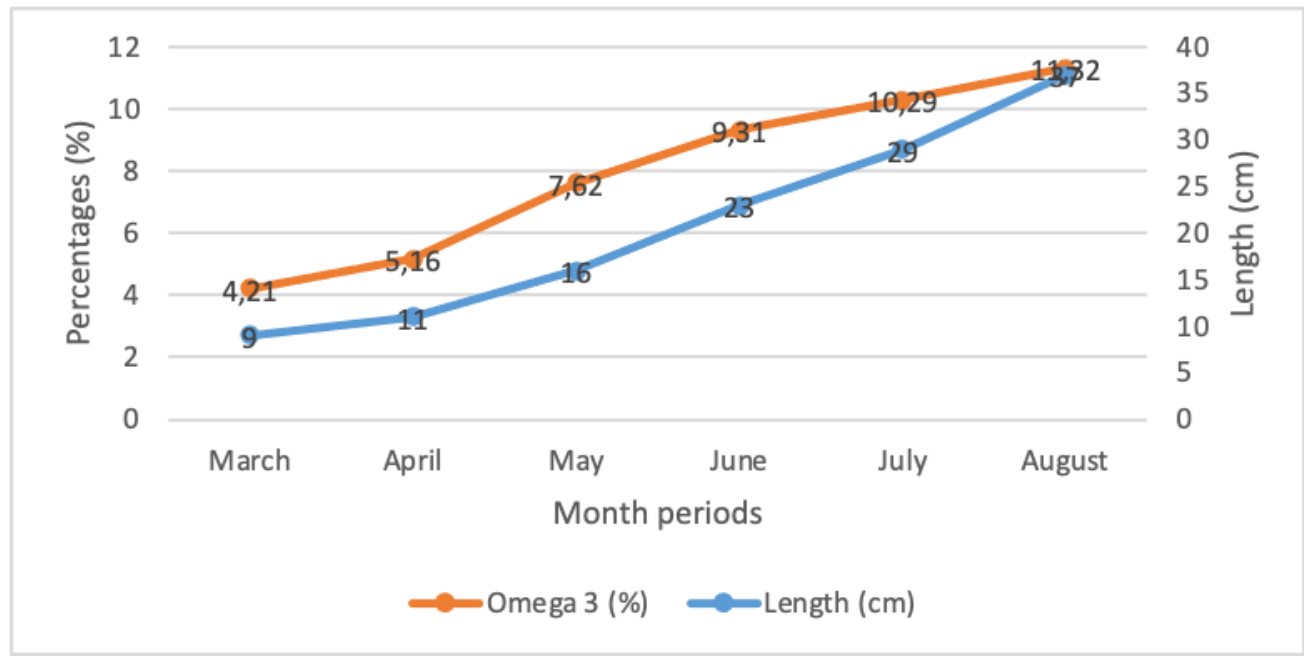

Fig. 4. Omega-3 fatty acid content and length of Chanos chanos.

The analysis of omega-3 fatty acids from the Chanos chanos body recodred a relatively high omega-3, that were seen from various lengths of fish (Fig. 3). It is worth mentioning that, the length and weight of the Chanos chanos are directly proportional to the omega-3 content in the body. The longer the body of the fish, the greater the omega-3 is in the body. In this context, the biggest Chanos chanos caught in September with an 
average size of $26 \mathrm{~cm}$ contained omega- 3 of $11.32 \%$ of the total fatty acids in the whole body .

\section{DISCUSSION}

The number of phytoplankton found in pond waters were nine species and zooplankton were eight species, while the density of phytoplankton ranged from 117 to 1070 cells/L and zooplankton ranged from 358 to 1153 ind/L. Phytoplankton predation by Chanos chanos was very high as indicated by the average frequency of types of food found in the digestive tract of 125 fish of Chanos chanos by $41.4 \pm 14.8 \%$ (Table 3 ), thus causing a very low phytoplankton density.

Phytoplankton growth requires adequate nutrients for metabolism. The most needed nutrients in water with regard to phytoplankton are carbon, nitrogen, and phosphorus. Each phytoplankton cell contains about 50\% protein and about $7-10 \%$ nitrogen (Barsanti \& Gualtieri, 2006). Phytoplankton need nitrogen for cell wall formation, cell metabolism, amino acid formation. Notably, nitrate is a stable compound of nitrogen which is an important nutrient for autotrophic organisms and is known as a limiting factor for growth. Nitrogen and phosphorus levels become a limiting factor if nitrogen levels are $<0.02 \mathrm{mg} / \mathrm{L}$ and phosphorus levels are $<0.005 \mathrm{mg} / \mathrm{L}$. Comparison of nitrogen and phosphorus levels if they are $<12$, then nitrogen becomes a limiting factor for phytoplankton growth, whereas if $>12$, phosphorus becomes a limiting factor for phytoplankton growth (Geider \& MacIntyre, 2004). In ponds, nitrate and phosphate levels every month range from $0-0.867(0.069) \mathrm{mg} / \mathrm{L}$ and $0-1,921(1.42) \mathrm{mg} / \mathrm{L}$ with an N/P ratio of 10.34 (Rustadi, 2009). Nitrogen and phosphate compounds in pond waters are not barriers in themselves, but the ratio of $\mathrm{N}$ and $\mathrm{P}$ concentrations is barrier for growth.

Chanos chanos is a plankton-eating fish that obtains its food by filtering water of its environment using long and tight gill filters (Coad, 2015). In this study, Chanos chanos could utilize most of the phytoplankton and zooplankton in pond waters as food and energy sources, so that the length and weight of the individual increases with time. Chanos chanos can consume several types of phytoplankton and zooplankton found in the waters according to their stage and age. Based on the lasrgest part index, the most widely used phytoplankton was Chaetoceros sp. with a range of 6.3-64.0, while the zooplankton group was Cyclop sp. with a range of 0-24.7.

The Chanos chanos diet consisted of phytoplankton, zooplankton, detritus, and plant residues in percentages of 43\%, 46\%, and 11\%, repectively (Aqil et al., 2013). The digestive system of Chanos chanos is different from other herbivorous fish, because Chanos chanos has a stomach that functions food storage temporarily, to stir or mix food with gastric sap and deliver food into the intestine, so that Chanos chanos is able to efficiently digest plankton. The entire surface of the stomach is covered by mucous cells which contain somewhat acidic mucopoly-carida, functioning as a protective wall of the stomach from the work of hydrochloric acid (Coad, 2015). Chanos chanos in ponds prey 
on phytoplankton and zooplankton, although the proportion of zooplankton is small. Chanos chanos food varies depending on the type of food available in the waters. The types of phytoplankton that are widely consumed are Chaetoseros sp. and Nitzschia sp., While the types of zooplankton are Calanus and Cyclop sp.

Chaetoceros sp. and Nitzschia sp. are types of lipid-producing organisms with a high lipid content reaching around 71.5\% (Geider \& MacIntyre, 2004), thus they supply Chanos chanos with the required energy. Moreover, Coad (2015) stated that Chanos chanos filter plankton, eat benthic organisms, cyanobacteria, diatoms, foraminifera, filamentous green algae, detritus, shellfish, snails, worms, and some crustaceans. Remarkably, phytoplankton cell walls are composed of cellulose, while zooplankton cell walls are composed of cell membranes. Cellulose is more difficult to digest than cell membranes, and thus, takes more time to digest phytoplankton. Chanos chanos with a total range of 15-25 cm length minimum have intestine length of 5.4 times the total body length (Table 6), hence that food can be digested completely. In addition, according to Bagarinao (1994), Chanos chanos have small mouths without teeth, soft and dense gill filters as food filtering devices, and a pair of muscles similar to an epibranchial raker organ. The esophagus is long and thick-walled, with 20-22 spiral folds and has many mucous cells, and a big belly, very thick-walled pylorus and mucous membranes. Stomach has glands that function in digesting food ingredients. The intestine is convoluted and very long. The entire digestive tract is circular and forms a compact mass in the abdominal cavity (Bagarinao, 1994).

Along with the growth of fish, Chanos chanos food in ponds has shifted. In small size with total length that is $<14 \mathrm{~cm}$ or the young aged, the main food is phytoplankton dominated by Chaetoceros sp. While, when the size is $>15 \mathrm{~cm}$ length, zooplankton becomes complementary food dominated by Calanus sp and Cyclop sp. The choice of Chanos chanos for certain types of plankton is determined according to their needs and availability in waters. At a young age, the energy requirements for growth are very high, thus consumption of Chaetoceros sp. and Nitzchia sp. becomes very high even reaching 1.5 times the concentration in waters. Furthermore, the type of chanos varies depending on the living stage and its habitat (Bagarinao, 1994).

Ontogeny of fish food that occurs in Chanos chanos in ponds is caused by a shift in the availability of food types and demands to meet their nutritional needs. The main food of adult Chanos chanos consists of benthic and planktonic organisms including gastropods, lamellibranchia, foraminifera, filamentous algae, diatoms, copepods, nematodes and detritus (Coad, 2015). The relationship of length and weight of Chanos chanos in pond waters has an isometric growth pattern, indicating that the additional length and weight of the Chanos chanos are proportional. The weight of Chanos chanos ranges from 2.78 to 3.46 (Froese \& Pauly, 2015), generally influenced by food availability, behavior, and habitat. The length-weight relationships of Chanos chanos cultivated in ponds showed isometric growth patterns with values of 2.89-3.15 (Biswas et al., 2011). The value indicated an isometric growth pattern dermining that fish are able to 
maintain a constant body shape with proportional increase in length and weight. The lenght-weight relationship pattern showed relative growth, which means that the lenghtweight relationship pattern would be allowed to change according to time (Jurniati et al. 2021).

\section{CONCLUSION}

Chanos chanos stocked in pond waters can utilize most types of plankton that are available as food sources. The most consumed phytoplankton species were Chaetoceros sp. and Nitzchia sp., While the most consumed zooplankton were Calanus sp. and Cyclop sp. The proportion of zooplankton increased with the size of Chanos chanos and was found in the digestive tract of fish $>15 \mathrm{~cm}$ in length. The total growth and daily growth rate of Chanos chanos in ponds was very good and could reach the size of consumption within six months after stocking. In conclusion, the length and weight of Chanos chanos are directly proportional to the omega- 3 content in the fish's body.

\section{ACKNOWLEDGMENTS}

Thanks to the University of Brawijaya and Ministry of Education and CultureResearch, Technology of Republic of Indonesia (Kemendikbud-ristek) who have provided funding for the research.

\section{REFERENCES}

Bagarinao, T. (1994). Systematics, distribution, genetics and life history ff milkfish, Chanos chanos. Environmental Biology of Fishes, 39(1): 23-41.

Barsanti, L. and Gualtieri, P. (2006). Algae: Anatomy, Biochemistry, and Biotechnology. Taylor \& Francis Group, New York, 301pp.

Biswas, S.P. (1993). Manual of method in Fish Biology. South Asian Publishers Pvt Ltd, New Dehli, 157pp.

Biswas, G. ; Sundaray, J.K. ; Thirunavukkarasu, A.R. and Kailasam, M. (2011). Length-weight relationship and variation in condition of Chanos Chanos (Forsskål, 1775) from tide-ded brackishwater ponds of the Sunderbans India. Indian Journal Geo-Marine Science 40(3): 386-390.

Bligh E.G. and Dyer W.J. (1959). A rapid method of total lipid extraction and purification. J. Biochem. Physiol. 37: 911-917.

Chong, K.C. ; Poemomo, A. and Kasryno, F. (1984). Economic and Technological Aspects Of The Indonesian Milkfish Industry. In: Juario JV, Ferraris RP, Benitez LV (Eds.) Advances in Milkfish Biology and Culture. Proceedings of the Second 
International Milkfish Aquaculture Conference, 4-8 October 1983, Iloilo City, Philippines, pp. 199-213.

Coad, B.W. (2015). Review of the milkfishes of Iran (Family Chanidae). Iranian Journal of Ichthyology, 2(2): 65-70.

Djumanto ; Setyobudi, E. ; Sentosa, A.A. ; Budi, R. and Nirwati, N. (2008). Reproductive biology of the yellow rasbora (Rasbora lateristiata) inhabitat of the Ngrancah River, Kulon Progo. Jurnal Perikanan, 10(2): 261-275.

Faradina, R.A; Rahadi, B and Suharto, B. (2015). Analisis Kelas Kemampuan Lahan Sebagai Penentu Kesesuaian Penggunaan Lahan di Kabupaten Sidoarjo. Jurnal Sumberdaya Alam dan Lingkungan, 2(2): 1-13.

Franklin, S.M. ; Mei-Chen, T. and Sin-Ping, Y. (2006). Milkfish (Chanos chanos ) culture: situations and trends. Journal of the Fisheries Society of Taiwan, 33(3): 229-244.

Froese, R. and Pauly, D. (2015). FishBase. World Wide Web Electronic Publication. www.fishbase.org (10/2019).

Geider, R.J. and MacIntyre, H.L. (2004). Physiology and biochemistry of photosynthesis and algal carbon acquisition. In : "Phyto-plankton Productivity Carbon Asimilation in Marine and Freshwater Ecosystem.” Williams, P.J, Thomas, D.N, and Reynolds, C.S (Eds). Blackwell Science Ltd., Oxford, 44-77pp.

Ivlev, V. S. (1961). Experimental Ecology of Feeding of Fishes. Yale University Press, New Haven. Connecticul. USA.

Jurniati ; Arfiati, D. ; Andriyono, S. ; Hertika, A.M.S. and Kurniawan, A. (2021). Morphometric-meristic characters and length-weight relationships of macrobrachium mammillodactylus (Thallwitz, 1892) inhabiting downstream of Rongkong Watershed, South Sulawesi, Indonesia. Egyptian Journal of Aquatic Biology \& Fisheries.25(1): $91-110$.

Nelson, J.S.; Grande, T.C. and Wilson, M.V.H. (2016). The Fishes of the World, Fifth edition. John Wiley \& Sons, Inc. Hoboken, New Jer-sey, 707 pp.

Morrison, W.R and Smith, L.M. (1964). Preparation of fatty acid methyl esters and dimethylacetals from lipids with boron fluoride-methanol. Journal of Lipid Research, 5(4):600-8.

Oldfield, R.G. ; Mccrary, J. ; and Mckaye, K.R. (2006). Habitat use, social behavior, and female and male size distributions of juvenile midas cichlids, Amphilophus cf. citrinellus, in Lake Apoyo, Nicaragua. Caribbean Journal of Science, 42(2): 197207. 
Prayitno, S.B. ; Sarwan and Sarjito. (2015). The diversity of gut bacteria associated with milkfish (Chanos chanos Forsskal) from northern coast of Central Java, Indonesia. Procedia Environmental Sciences, 2 (1): 375-384.

Shirota, A. (1996). The Plankton of South Vietnam: Freshwater and Marine Plankton. Overseas Technology Cooperative Agency. Tokyo, Japan, 463pp.

Verlencar, X.N. (2004). Phytoplankton Identifica-tion Manual. National Institute of Oceanography, Dona Paula, Goa, 35pp. 